\title{
COMMUNICATIONS.
}

\section{THE RECENT PSYCHOLOGICAL CONGRESS AT PARIS.}

The members of the Psychological Congress have just taken leave of one another, after six days of discussion, conversation, and stimulating social intercourse. The Congress was opened on the 2oth of August, under the chairmanship of $M$. Th. Ribot. Although older in appearance, M. Ribot showed bimself no less active and alert than in the days of 1889 . His voice was no less distinct, and his bright, clear eyes were ever wide open as if to catch the light which streamed from the persons and spirit of his audience. His opening address was extremely simple, as is his person; he touched as briefly as possible upon the work which had been accomplished since the Congress of Munich four years ago, and he referred in conclusion to the necessity, now entailed by the overwhelming mass of psychological material, of revising and epitomising results with a view to facilitating investigation and preparing the way for partial syntheses.

After M. Ribot, who had spoken only twenty or twenty-five minutes, came Professor Ebbinghaus, of Breslau, who spoke for a whole hour. This latter gentleman toppled over the psychologists of a hundred years ago in magnificent style, and seemed to derive the deepest satisfaction from their demolition. Professor Ebbinghaus has presence and a fine voice, but also something of the consequential arrogance of an officer examining young recruits. His merit, which is real, would be much more appreciated if he evinced some slight degree of modesty, and did not attribute to himself such excessive importance.

The assembly then split up into seven sections : (I) Psychology in its relations to anatomy and physiology, with M. Mathias Duval as president ; (2) Introspective psychology in its relations to philosophy, with M. Séailles as president ; (3) Experimental and psychophysical psychology, with M. Binet as president ; (4) Pathological and psychiatrical psychology, with M. Magana as president; (5) The psychology of hypnotism, suggestion, and related questions, with M. Bernbeim as president; (6) Social and criminal psychology, with M. Tarde as president; (7) Animal and comparative psychology, anthropology, and ethnology, with $M$. Yves Delage as president. 
In each of these sections interesting communications were made, and useful observations exchanged, but they bore upon subjects too widely different for us to speak of them in any detail. It will doubtless be pleasing to the readers of 7he Monist to learn that the address of Dr. Carus, which was delivered before the second section, was well received, and also discussed, principally by the Rev. P. Bulliot, Professor of Philosophy in the Catholic Institute of Paris, an acute thinker. Several ecclesiastics attended the sessions of the Congress, and the increased ardor with which the French clergy are now participating in the work of modern science is a feature to be noted.

In the fifth section, the epithet "related subjects " referred clearly to telepathy, spiritualism, etc. M. Myers himself was present, and spoke before quite a large audience, among whom were many ladies.

M. Myers, who held the attention of his audience, was succeeded by an orator who lapsed into trivialities, and the session was in danger of being brought to a close by the unbridled narration of ghost stories, if the discussion had not been brought back to the main question at issue by the ruling of the chairman, and had not the flood of futile words been arrested which discussions of this sort ordinarily provoke when they are abandoned to persons devoid of critical power.

In fine, the dominating tendency of the Congress was to restrict discussions to positive issues, and to take its stand upon the ground of carefully conducted experiments and carefully made observations.

In closing, words of sincerest courtesy were exchanged among the members of the different nations, - not the least profitable feature of this Congress, - and it was agreed to meet again at Rome in four years. May all of the distinguished persons who were here present join hands there again in the full vigor of life and intellect!

Paris, August 25, Igoo.

A. L. 